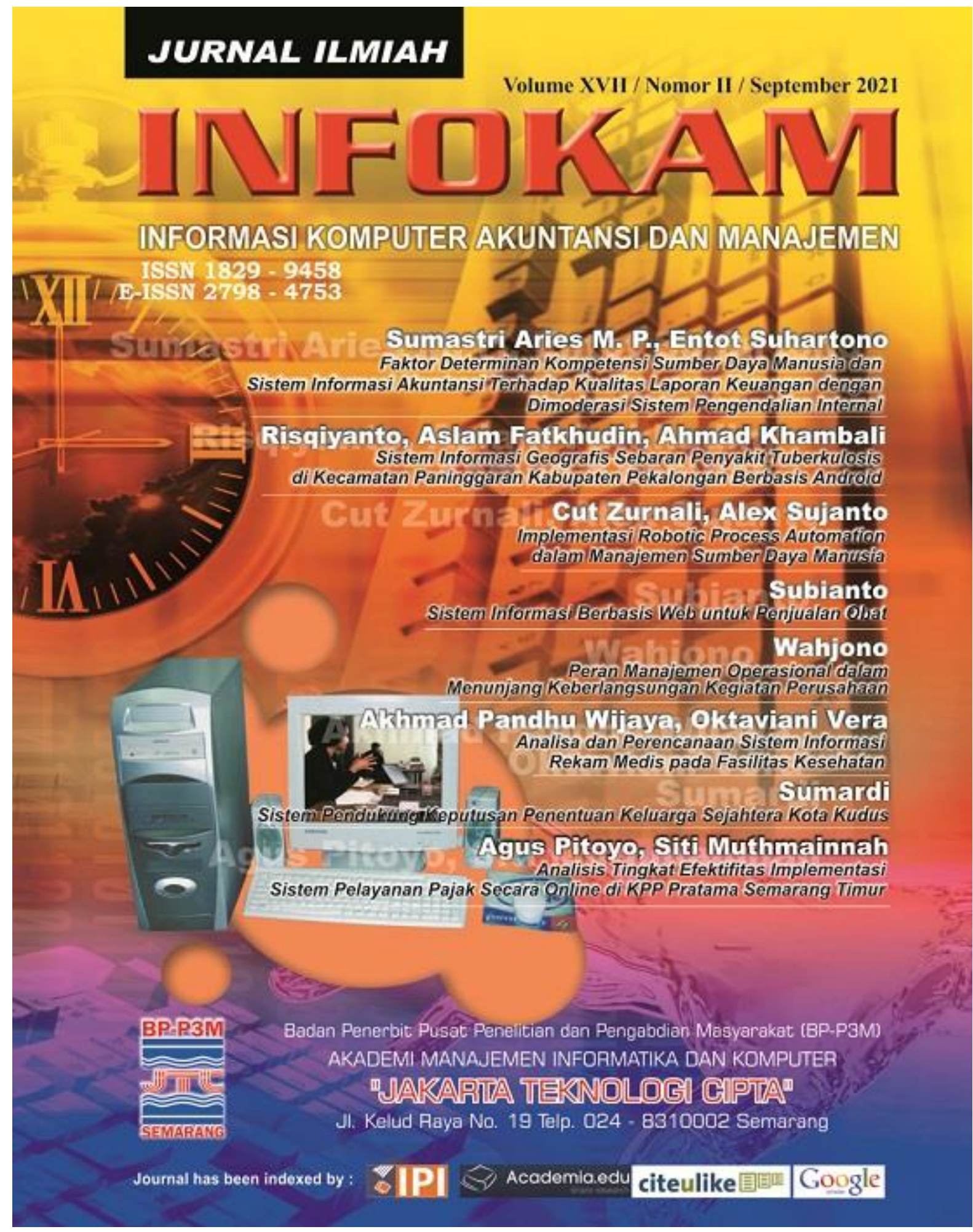


INFORMASI KOMPUTER AKUNTANSI DAN MANAJEMEN

ISSN 1829 - 9458

E-ISSN 2798 - 4753

SK DIREKTUR AMIK "JTC" SEMARANG

NO. 6305/AMIKJTC/D/IX/2020

Penasehat : Dr. Alex Sujanto, SE, S.Pd, MM. (Direktur)

Pengarah : Kristiawan Nugroho, M.Kom (Pudir I)

Muhamad Danuri, M.Kom (Pudir III)

Penanggung Jawab : Sumardi, S.Kom, M.Kom (Ka Progdi KA)

Subianto, S.Kom, M.Kom (Ka.Progdi MI)

Ketua Dewan Redaksi

Wahjono, SE, M.Si (Ketua Editor)

Sekretaris Editor

Anton Sujarwo, M.Si

Bendahara

Agus Pitoyo, M.Si

Anggota Dewan Editor

Subianto, M.Kom

Sumardi, M.Kom

Dr. Heru Sulistyo, SE, MSI ( STIE Dharmaputra Semarang)

Agus Prasetyo Utomo, MM., M.Kom (Univ. Stikubank Semarang)

Ira Setiawati, SE, M.Si (Univ. PGRI Semarang)

Eko Riyanto, S.Pd, M.Kom (STMIK Himsya Semarang)

Editor Teknis Dan Pelaksana

Sugeng Murdowo, S.T, S.Kom, M.Kom

Dr. Alex Sujanto, SE, S.Pd, MM

Mitra Bestari Peer Reviewer

Komputer

Daniel Alfa Puryanto, M.Kom (STMIK AKI Pati)

Aslam Fathkudin, M.Kom (Univ. Muh. Pekajangan Pekalongan)

Entot Suhartono, M.Kom (Univ. Dian Nuswantoro)

Fata Nida'ul Khasanah, M.Eng (Univ. Bhayangkara Jakarta Raya)

Noor Azizah, S.Kom, M.Kom (Univ. Islam Nahdatul Ulama Jepara)

\section{Akuntansi}

Dr. Heru Sulistiyo, M.Si, Akt (STIE Dharmaputra Semarang)

Arini Novandalina, M.Si (STIE Semarang)

Manajemen

Prof. Dr. Amron, SE. MM (Univ. Dian Nuswantoro Semarang)

Entot Suhartono, M. Kom (Univ. Dian Nuswantoro Semarang)

\section{Section Editor}

Subianto, S.Kom, M.Kom

Jurnal Ilmiah INFOKAM terbit minimal setiap 6 bulan sekali $(2 \mathrm{X}$ dalam setahun, bulan Maret \& September ) oleh AMIK "JTC" Semarang dengan maksud sebagai media informasi tentang Komputer, Akuntansi dan Manajemen bagi Sivitas Akademika pada khususnya dan masyarakat pada umumnya.

Alamat Redaksi / Penerbit :

Badan Penerbit Pusat Penelitian dan Pengabdian Masyarakat (BP-P3M)

AKADEMI MANAJEMEN INFORMATIKA DAN KOMPUTER

"JAKARTA TEKNOLOGI CIPTA"

Jl. Kelud Raya No. 19 Telp. 024 - 8310002 Semarang www.amikjtc.com/jurnal, email : infokam.amikjtc@gmail.com 


\section{INFORMASI KOMPUTER AKUNTANSI DAN MANAJEMEN \\ ISSN 1829 - 9458 \\ E-ISSN 2798 - 4753}

\section{DAFTAR ISI}

Faktor Determinan Kompetensi Sumber Daya Manusia dan Sistem Informasi Akuntansi Terhadap Kualitas Laporan Keuangan dengan Dimoderasi Sistem Pengendalian Internal

Sumastri Aries M. P., Entot Suhartono

Sistem Informasi Geografis Sebaran Penyakit Tuberkulosis di Kecamatan Paninggaran Kabupaten Pekalongan Berbasis Android

Risqiyanto, Aslam Fatkhudin, Ahmad Khambali

Implementasi Robotic Process Automation Dalam Manajemen Sumber Daya Manusia

Cut Zurnali, Alex Sujanto

Sistem Informasi Berbasis Web untuk Penjualan Obat

Subianto

Peran Manajemen Operasional dalam Menunjang Keberlangsungan Kegiatan Perusahaan

Wahjono

Analisa dan Perencanaan Sistem Informasi Rekam Medis pada Fasilitas Kesehatan

Akhmad Pandhu Wijaya, Oktaviani Vera

Sistem Pendukung Keputusan Penentuan Keluarga Sejahtera Kota Kudus Sumardi

Analisis Tingkat Efektifitas Implementasi Sistem Pelayanan Pajak Secara Online di KPP Pratama Semarang Timur Agus Pitoyo, Siti Muthmainnah 


\title{
Peran Manajemen Operasional dalam Menunjang Keberlangsungan Kegiatan Perusahaan
}

\author{
Wahjono \\ Program Studi Manajemen Informatika \\ AMIK JAKARTA TEKNOLOGI CIPTA \\ wahyono.amikjtc@gmail.com
}

\begin{abstract}
Abstrak
Keberlangsungan sebuah organisasi atau perusahaan pasti akan memiliki bagian yang khusus menangani pengelolaan operasional. Manajemen operasional suatu perusahaan terlihat kinerjanya dari tujuan pengelolaan operasionalnya. Faktor penyebab pengelolaan operasional dianggap penting dalam sebuah perusahaan yaitu : Berperan dalam pencapaian tujuan; Meningkatkan produktivitas karyawan; Meningkatkan niat baik; Pemanfaatan sumber daya yang optimal dan Memotivasi karyawan. Seorang manajer harus paham tentang semua proses didalam suatu perusahaan. Keterlibatan dari koordinasi dalam suatu proses dengan perkembangan terbaru sambil mengevaluasi kembali strukturnya. Yang paling utama tugas dan peran seorang Manajer operasional adalah mempunyai tanggungjawab atas kelangsungan dari hasil produksi, baik berupa kuantitas ataupun kualitasnya.

Kata kunci: Manajemen, Operasional, Perusahaan

Abstrack

The continuity of an organization or company will definitely have a section that specifically handles operational management. Operational management of a company looks at its performance from the objectives of its operational management. Factors causing operational management are considered important in a company, namely: Play a role in achieving goals; Increase employee productivity; Increase goodwill; Optimal resource utilization and Motivating employees. A manager must understand all processes in a company. The involvement of the coordination in a process with the latest developments while re-evaluating its structure. The most important task and role of an operational manager is to have responsibility for the continuity of production results, both in terms of quantity and quality.

Keywords: Management, Operations, Company
\end{abstract}

\section{Pendahuluan}

Didalam keberlangsungan sebuah organisasi atau perusahaan pasti akan memiliki bagian yang khusus menangani pengelolaan operasional. Dalam pengelolaan operasional disetiap organisasi atau perusahaan sangat beragam dan disesuaikan dengan kebutuhan pada organisasi perusahaan masing-masing. Pada dasarnya peran dari manajemen operasional sangatlah penting demi keberlangsungan suatu perusahaan. Memang dalam setiap pebisnis akan paham pentingnya tugas dari manajemen keuangan dan manajemen pemasaran. Tetapi, disamping dari kedua bagian tersebut, terdapat bagian lain yang tidak kalah penting untuk kegiatan bisnis yakni manajemen operasional.

Dengan semakin ketatnya persaingan bisnis dan semakin berkembangnya kemajuan teknologi yang semakin meningkat pula, adanya persaingan bisnis yang semakin ketat juga menyebabkan manajer operasional pada suatu perusahaan harus pandai dalam mengelola modal kerja perusahaan mereka secara efektif agar dapat melampaui pesaingnya sehingga perusahaan dapat menjaga kelangsungan hidupnya.

Dalam hal ini peran dari manajemen operasional dituntut untuk dapat mengikuti dari perkembangan teknologi agar tidak kesulitan dalam menangani dan mengelola operasional perusahaan. Peran teknologi Informasi dalam penanganan masalah operasional perusahaan sangat diperlukan untuk menunjang kelancaran dan keamanan setiap operasional yang dikelolanya. 
Dalam suatu perusahaan yang menentukan jumlah keuntungan serta daya tahan dalam sebuah bisnis, salah satunya adalah sistem operasionalperusahaan. Dapat disimpulkan, apabila dalam kegiatan bisnis tidak ada sistem operasional yang baik dan terkendali, maka bisa dimungkinkan bisnis itu akan susah berkembang. Karena dalam suatu bisnis sistem operasional mempunyai tugas untukmengelola seluruh sumber daya yang dimiliki perusahaan.

\section{Landasan Teori}

\section{a. Pengertian Manajemen Operasional}

Heizer dan Render (2010) berpendapat bahwa yang dimaksud dengan manajemen operasional ialah merupakan bentuk dari pengelolaan yang menyeluruh secara optimal dari tenaga kerja, barang-barang (bahan mentah, peralatan dan mesin), atau dari berbagai faktor produksi yang lain agar dapat menjadi bentuk produk barang dan jasa yang dapat diperjualbelikan secara umum.

Selain itu ada pengertian lain tentang operation management yaitu dapat diartikan juga sebagai pengelolaan, yang terdiri dari bentuk rencana, pengorganisasian, pengkoordinasian, mengendalikan dari seluruh kegiatan-kegiatan yang berhubungan dengan penanganan baik berbentuk barang maupun berbentuk jasa secara langsung.

Sedangkan dari sumber lainnya arti manajemen operasional adalah merupakan aplikasi dari disiplin ilmu manajemen yang digunakan untuk pengaturan segala kegiatan produksi supaya dapat beroperasi secara efektif dan efisien. Definisi yang lain, operation management adalah suatu proses yang terusmenerus secara efektif untuk memanfaatkan semua fungsi manajemen yang terintegrasi dari beberapa sumber daya dengan efisien untuk dapat terwujudnya tujuan suatu perusahaan.

Sedangkan menurut Kumar dan Suresh (2009), menyampaikan pengertian bahwa merupakan kegiatan manajemen yang terintegrasi terdiri dari kegiatan manufaktur hasil produk kemudian memberikan pelayanan sebagai manajemen produksi dan operasi. Kegiatan operasional digambarkan sebagai proses transformasi seperti terlihat pada Gambar 1.

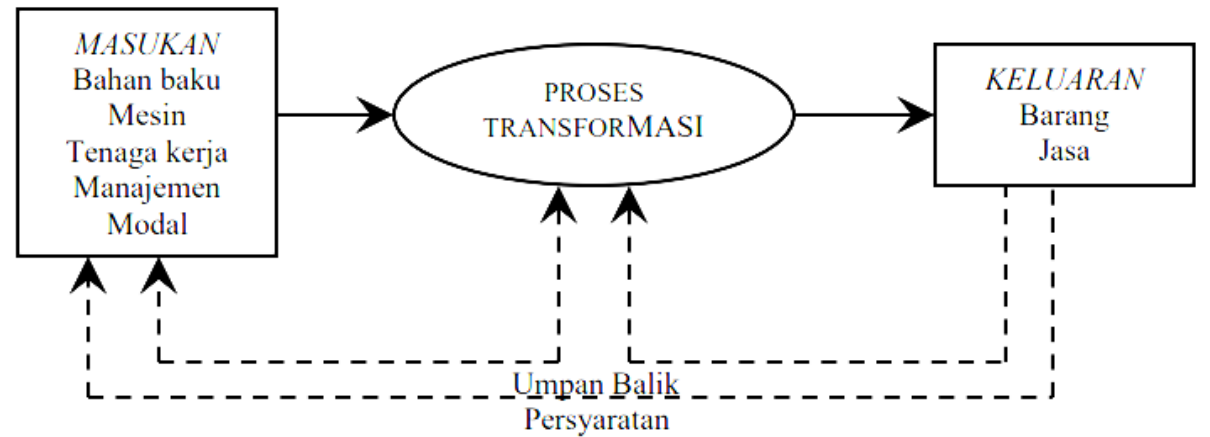

Sumber: Russell dan Taylor (2011).

Gambar 1. Operasional dari Fungsi Transformasi

Jadi dapat dirangkum dari pengertian-pengertian manajemen operasional dan definisi di atas adalah bersumber dari pengelolaan sumber daya bisnis yang terdiri dari produk barang dan jasa agar aktivitas bisnis berjalan efisien. Oleh sebab itu, operation management, memerlukan struktur kepengurusan yang dibentuk dan dilaksanakan sesuai fungsi masing-masing. Sebagai pemimpin tertinggi dalam struktur tersebut ialah manajer operasional.

\section{b. Tujuan Manajemen Operasional}

Tujuan dari Penerapan operation management adalah untuk pengaturan dari penggunaan sumber daya yang dimiliki perusahaan. Yang dimaksud dengan sumber daya tersebut adalah terdiri dari bahan mentah untuk pembuatan produk, tenaga kerja, peralatan produksi, serta perlengkapan lainnya. Dengan Harapan, apabila diatur secara baik maka proses produksi dapat berlangsung secara efektif dan efisien berkat sistem operasional yang tepat. Secara rinci, operation management memiliki lima tujuan yaitu: 
1) Efficiency, operasional perusahaan diusahakan untuk lebih efisien.

2) Productivity, Tingkat produktivitas perusahaan diupayakan semakin meningkat.

3) Economy, meminimalkan biaya atau pengeluaran kegiatan yang dilakukan perusahaan agar beban perusahaan semakin ekonomis.

4) Quality, kualitas dari perusahaan diusahakan semakin meningkat, baik peningkatan produk maupun jasa.

5) Reduced processing time, mengurangi waktu proses produksi. Karena apabila terjadi berkurangnya waktu produksi, hasil produkpun makin banyak.

\section{c. Karakteristik Manajemen Operasional}

Karakteristik yang dimiliki dari sistem pengelolaan Manajemen Operasional adalah:

1) Ditujukan untuk memproduksi barang dan jasa

Pengelolaannya ditekankan dengan tujuan untuk pengaturan dalam proses produksi baik untuk produksi barang dan jasa secara menyeluruh agar menghasilkan pendapatan perusahaan.

2) Terdapat kegiatan yang melibatkan proses transformasi

Semua kegiatan yang menggunakan satu atau lebih input, dengan cara mengubah dan menambahkan nilai ke dalamnya, kemudian akan menghasilkan output untuk kebutuhan pelanggan atau klien, inilah yang merupakan proses transformasi.

Apabila bentuk input-nya berupa bahan baku, maka akan relatif lebih mudah untuk mengidentifikasi transformasi yang terjadi contohnya ketika susu diubah menjadi keju dan mentega. Akan tetapi, apabila input-nya dalam bentuk informasi atau manusia, maka sifat transformasinya menjadi sulit untuk diukur. Misalnya, rumah sakit mengubah pasien yang sakit (input) menjadi pasien sehat (output).

\section{d. Pengertian Perusahaan}

Pengertian dari Perusahaan adalah merupakan sebuah unit kegiatan produksi yang mengolah sumber daya ekonomi untuk menyediakan barang dan jasa bagi masyarakat dengan tujuan memperoleh keuntungan dan memuaskan kebutuhan masyarakat (Murti Sumarni,1997)

Sedangkan pengertian menurut Basu Swastha dan Sukotjo (2002 : 12) perusahaan adalah suatu organisasi produksi yang menggunakan dan mengkoordinir sumber-sumber ekonomi yang ada untuk dapat memuaskan kebutuhan masyarakat dengan maksud untuk mendapat keuntungan.

Di dalam Undang Undang Nomor 3 Tahun 1982 pengertian istilah Perusahaan merupakan setiap bentuk usaha yang bersifat tetap, terus menerus, didirikan, bekerja dan berkedudukan di wiayah negara Republik Indonesia dengan tujuan untuk memperoleh keuntungan (laba).

Dari isi undang-undang tersebut terlihat bahwa mengandung definisi perusahaan yang terdiri dari dua unsur pokok, yaitu:

1) Bentuk usaha (company) bentuk usaha ini berupa suatu organisasi atau badan usaha yang didirikan, bekerja dan berkedudukan dalam wilayah negara Indonesia.

2) Jenis usaha (business) ini berupa kegiatan bidang perekonomian (perindustrian, perdagangan, perjasaan, pembiayaan) yang dijalankan oleh badan usaha secara terus menerus.

\section{Pembahasan}

\section{a. Pentingnya Manajemen Operasional dalam Bisnis}

Dalam suatu perusahaan, manajemen operasional sangat penting perannya dan dapat terlihat dari tujuan pengelolaan operasional dalam kegiatan bisnis. Faktor penting yang membuat pengelolaan operasional bisnis dapat berjalan lancar dalam sebuah perusahaan adalah:

\section{1) Membantu dalam pencapaian tujuan}

Peran Manajemen operasional memiliki efektifitas untuk pencapaian tujuan yang telah direncanakan sebelumnya. Manajemen operasional dapat dengan pasti menentukan bahwa semua aktivitas operasional perusahaan berjalan sesuai dengan rencana dengan cara terus memantau semua kerja dalam perusahaan. 


\section{2) Peningkatan produktivitas karyawan}

Manajemen operasional akan berupaya untuk meningkatkan produktivitas semua karyawan. Bukan hanya dengan mengukur kinerja para karyawannya saja, akan tetapi juga pengelolaan operasional dapat memberikan pelatihan dan mendidik karyawan agar dapat meningkatkan kinerja.

3) Peningkatan niat baik

Untuk membantu meningkatkan niat baik dalan mempertahankan nama baik dan keberadaan perusahaan, Manajemen operasional harus dapat memberikan kepastian bahwa produk yang dihasilkan mempunyai kualitas yang bagus untuk dapat dikirimkan ke semua pelanggan sehingga bisa memberikan kepuasan dan kebahagiaan kepada mereka.

4) Optimalisasi pemanfaatan sumber daya

Dalam pengelolaan operasional akan berupaya untuk tetap fokus pada pemanfaatan sumber daya perusahaan yang optimal. Yaitu dengan menggunakan strategi yang tepat dalam pemilihan cara operasional perusahaan, melakukan pengawasan yang ketat terhadap semua aktivitas, dan memastikan semua sumber daya digunakan tidak terbuang.

5) Memotivasi karyawan

Memotivasi karyawan sangatlah penting bagi manajemen operasional dengan cara membantu setiap karyawannya agar dapat memahami peran masing-masing. Manajer operasional dapat membimbing semua karyawan dalam menjalankan peran mereka dalam perusahaan dan menciptakan suasana yang menyenangkan sehingga dapat mendukung produktivitas kerjanya. Untuk merangsang peningkatan kinerja karyawan, maka Karyawan juga diberikan penghargaan sesuai dengan tingkat kinerja mereka.

\section{b. Strategi Manajemen Operasional}

Dalam penyusunan strategi operasionalnya, Manajemen Operasional selalu akan didasarkan pada persoalan internal, yaitu keberadaan sumber daya perusahaan termasuk di dalamnya adalah teknologi, serta tidak kalah pentinya juga persoalan eksternal, yaitu perhitungan tentang kebutuhan pasar.

Dalam kenyataannya di lapangan, banyak perusahaan yang mengkombinasikan antara persoalan internal dan eksternal (kebutuhan pasar) dalam penyusunan strategi operasionalnya. Strategi-strategi itu adalah:

1) Isi Strategi

Strategi yang disusun berhubungan dengan pemenuhan kebutuhan pasar yang ada dengan cara memanfaatkan peluang yang ada untuk kepentingan segmen pasar yang potensial. Sedangkan strategi yang dibuat akan sangat bergantung pada misi perusahaan, Sehingga perlu ditekankan disini isi dari strategi operasional dari Manajemen Operasional harus terdapat sejumlah konten yang perlu diprioritaskan ada dalam menyusun strategi manajemen operasional.

\section{2) Perancangan proses}

Dalam perancangan proses operasional perlu diadakannya penelitian, memperkirakan, dan mengembangkan proses yang dalam hal ini akan membutuhkan keahlian dan energi yang nantinya hasil dari rancangan ini dapat bertahan lama.

\section{3) Membuat Inovasi}

Dalam melakukan kegiatannya manajmene operasional selalu melakukan perubahan dan pembaruan proses agar outputyang dihasilkan perusahaan akan terus berkembang sesuai dengan perubahan dilingkungan eksternal.

4) Pemanfaatan Data

Pada saat menganalisa untuk membuat perencanaan yang kuat, membuat penyesuaian dan pengambilan keputusan. Ada dua jenis yang umum dilaksanakan yaitu data yang berbentuk metrik efisiensi dan metrik efektivitas.

5) Pengaturan Manajemen supply chain

Peranan dari Manajemen hubungan dengan pihak eksternal yaitu pengaturan dengan pemasok untuk dapat memastikan bahwa pasokan (supp/y) berjalan secara efektif dan efisien.

\section{6) Pembuatan Analisis Inventaris}

Dalam Pengelolaan inventaris untuk rantai pasokan, bentuk analisis $A B C$ (juga disebut analisis Pareto) sangat berperan. Ini dapat membagi pengelolaan persediaan 
menjadi tiga kategori $A, B$, dan $C$. " $A$ " memiliki nilai yang paling banyak dan kontrol yang paling ketat, sedangkan " $C$ " paling sedikit.

\section{c. Peran Manajer Operasional}

Sesuai dalam arti dari manajemen operasional, keseluruhan proses yang ada didalam suatu perusahaan harus benar-benar dapat dipahami oleh seorang Manajer Operasional. Manajer harus selalu terlibat dalam pengkoordinasian dalam suatu proses sekaligus memahami perkembangan terbaru dengan selalu melakukan evaluasi pada strukturnya.

Dalam pelaksanaannya seorang manajer operasional sangat butuh suatu organisasi dan produktifitas dari semua karyawannya. Manajer juga harus dapat berada di posisi yang sangat fleksibel.

Seorang Manajer Operasional memiliki tugas pokok dalam proses produksi, diantaranya adalah :

1) Membuat dan menentukan suatu perencanaan tentang kuantitas dan kualitas bahan baku untuk pelaksanaan proses produksi.

2) Membuat suatu perencanaan dimana lokasi gudang persediaan dan peralatan mesin yang efisien agar dapat menghemat waktu dan distribusi.

3) Melakukan perencanaan tata letak layout pada lokasi pabrik.

4) Sangat bertanggungjawab atas pemeliharaan dari peralatan pabrik agar selalu terjamin keandalan dan keberlangsungan operasional pabrik.

5) Membuat suatu perencanaan strategi untuk jenis produk yang mempunyai kualitas yang tinggi sehingga dapat bersaing dengan kompetitor.

6) Membuat dan menentukan suatu jadwal kerja yang efektif dan efisien sehingga akan dapat dilakukan evaluasi biaya tenaga kerja yang terbaik.

7) Seorang Manajer operasional sangat bertanggungjawab atas keberlangsungan suatu hasil produksi, baik dari sisi kuantitas maupun kualitas.

\section{d. Jenis Keputusan yang dilakukan Manajemen Operasional}

1) Proses yaitu seorang manajer harus dapat menentukan fasilitas yang digunakan dan keberlangsungan proses fisik.

2) Kapasitas yakni seorang manajer harus dapat menentukan berapa jumlah produksinya dan perkiraan waktu penyelesainnya.

3) Persediaan yaitu seorang manajer harus dapat memberikan keputusan apa saja bahan produksi yang dibutuhkan dan menentukan seperti apa kualitas dan kuantitasnya. Selain itu juga dapat menentukan kapan barang baku dipesan.

4) Tenaga dalam hal ini manajer harus terlibat dalam rekruitmen, PHK dan penggajiannya. Manajer juga harus dapat melakukan supervisi, kompensasi promosi jabatan dan penggunaan tenaga profesional.

5) Kualitas yaitu seorang manajer dapat menentukan ukuran standard, bentuk desain peralatan, model pengawasan produk dan sebagainya.

\section{e. Fungsi dari Manajemen Operasional}

Dalam kegiatannya secara umum terdapat empat macam fungsi dari Manajemen Operasional, diantaranya adalah :

\section{1) Fungsi Perencanaan}

Manajer operasional dalam melakukan perencanaan dapat menentukan suatu tujuan subsistem operasi dari suatu organisasi dan dapat melakukan pengembangan dari sebuah program, menentukan kebijakan dan prosedur yang digunakan dalam rangka untuk pencapaian suatu tujuan.

Dalam kegiatan ini manajemen operasional harus dapat menentukan peranan dan fokus dari operasional perusahaan, termasuk disini adalah melakukan perencanaan produk, perencanaan fasilitas dan perencanaan penggunaan sumber daya produksi.

2) Fungsi Pengorganisasian

Dalam mengatur suatu organisasi, seorang manajer operasional dapat menentukan sebuah struktur individu, grup, seksi, bagian, divisi atau departemen dalam suatu subsistem operasi sehingga dapat mencapai suatu tujuan organisasi. 
Manajer operasi juga mempunyai tugas untuk menentukan kebutuhan sumber daya yang diperlukan dalam pencapaian suatu tujuan operasi serta dituntut untuk dapat mengatur wewenang dan tanggung jawab yang diperlukan dalam pelaksanaannya.

3) Fungsi Penggerakan

Fungsi dari Menajemen operasional ini adalah melakukan tugas dengan dasar kepemimpinan, mengawasi dan memotivasi karyawan untuk melaksanakan tugas.

\section{4) Fungsi Pengendalian}

Dalam fungsi ini Manajemen operasional akan mengembangkan dan menentukan standar dan jaringan komunikasi agar sebuah pengorganisasian dan penggerakan dapat sesuai dengan yang direncanakan dan dapat mencapai tujuan.

\section{f. Ciri-Ciri Manajemen Operasional}

Menurut Zulian Yamit (2003), Manajemen operasional mempunyai Karakteristik sebagai berikut :

1) Mempunyai tujuan untuk dapat menghasilkan barang dan jasa.

2) Memiliki kegiatan yang utama yakni dalam kegiatan proses transformasi.

3) Mempunyai suatu mekanisme yang dapat mengendalikan suatu pengoperasian.

\section{g. Hubungan Manajemen Operasional dengan "Supply Chain"}

Pengertian dari Supply chain dapat diartikan dengan logistik. Pada bagian ini sangat berhubungan dengan proses produksi dan distribusi barang.

Dalam kegiatan ini, "supply chain" melakukan pengaturan distribusi barang ke suplier, melakukan kegiatan manufaktur dan melakukan retailer sehingga hasil produksi dapat sampai ke tangan konsumen. Pada prinsipnya "supply chain" akan selalu dapat berhubungan langsung dengan produk jadi sehingga dapat mengirim informasi yang berhubungan dengan kegiatan yang dilakukan oleh perusahaan seperti barang-barang yang dibutuhkan di perusahaan.

Kegiatan dari Manajemen operasional ini sangat erat kaitannya dengan "supply chain" atau SCM (supply chain management). Manajer operasional juga harus paham tentang tren global dan lokal, selain itu juga memahami permintaan konsumen dan kapasitas bahan produksi.

\section{h. Bertanggung Jawab pada Pengiriman Hasil Produksi}

Tanggung jawab manajemen operasional yang merupakan tugas besar ini adalah menjadi penyalur utama atau pendistribusian hasil produksi ke konsumen. Manajer juga harus dapat memastikan hasil produk dapat sampai dalam jangka waktu yang sudah di tertentukan.

Selain itu, bagian ini dapat melakukan kontrol kualitas secara langsung ke konsumen apakah produk yang dihasilkan sudah layak dan dapat memenuhi kebutuhan mereka. Sehingga diharapkan nantinya akan dapat menerima feedback langsung dari konsumen dan menyampaikan informasi dari konsumen ini sebagai bahan untuk melakukan suatu proses pengembangan.

Pihak manajemen operasional ini tidak hanya terbatas pada hasil produk yang berwujud fisik saja. tetapi organisasi atau perusahaan ini terdiri dari dua macam produksi yaitu berupa barang yang bisa disimpan dan jasa. Kedua hasil produksi ini ada perbedaan yang mencolok. Ketika membicarakan hasil produksi yang berupa barang fisik, konsumen tidak terlibat kontak secara langsung dan mereka dipisahkan oleh suatu proses pengiriman dan akhirnya mereka membeli produk langsung melalui reseller atau retailer-nya.

Tetapi, untuk produk yang berupa servis (jasa), konsumen dapat terlibat secara langsung dan dapat melihat secara langsung proses servisnya. Selain itu konsumen juga dapat berhubungan langsung dengan operasionalnya. Misalnya pada salon, bengkel dan sejenisnya. Sehingga kualitas operational management khusus untuk bidang jasa atau service, pelayanan manajemennya akan lebih ditekankan di bagian ini.

\section{i. Kegiatan Manajemen Operasional Disektor Barang dan Jasa}

Penciptaan produk dan layanan jasa dapat dilakukan pada semua organisasi atau perusahaan. Untuk perusahaan berbentuk manufaktur yang menghasilkan produk, kegiatan operasional ini akan lebih terlihat nyata. Sedangkan pada perusahaan jasa yang 
memberikan pelayanan kepada pelanggan, kegiatan operasional tidak terlalu tampak, tetapi dapat dirasakan. Menurut Chase et al (2006) Manajemen operasi juga dapat didefinisikan sebagai serangkaian kegiatan yang meliputi desain, operasi, dan perbaikan sistem yang menciptakan dan menyampaikan produk dan jasa atau layanan. Dalam hal ini kegiatan manajemen operasional pada sektor barang dan jasa adalah sebagai berikut :

1) Produk Barang

Kegiatan manufaktur, perkebunan, pertanian, perikanan, pabrik pembuatan produk barang, pertambangan, industri berat dan ringan, konstruksi, otomotif, perumahan.

\section{2) Produk Jasa}

Pendidikan, Jasa professional, hukum, kesehatan, perdagangan, transportasi, layanan masyarakat, perbankan, asuransi, hiburan, administrasi, real estate, serta jasa perbaikan.

\section{Kesimpulan}

a. Peranan Manajemen operasional dalam suatu perusahaan dapat terlihat dari tujuan dari pengelolaan operasional Perusahaan.

b. Tugas utama dan peran seorang Manajer operasional adalah bertanggungjawab atas keberlangsungan suatu hasil produksi, baik dari sisi kuantitas maupun kualitas.

c. Tanggung jawab besar yang merupakan tugas utama dari manajemen operasional adalah menjadi penyalur utama atau distributor utama dari hasil produksi ke konsumen.

d. Manajemen operasional harus dapat memberikan kepastian bahwa produknya sampai dalam jangka waktu tertentu sesuai dengan kebutuhan konsumen.

\section{Daftar Pustaka}

Basu Swastha dan Ibnu Sukotjo. 2002. Pengantar Bisnis Modern, Edisi Keenam, Yogyakarta: Liberty

Chase, R.B.; F.R. Jacobs; dan N.J. Aquilano. 2006. Operations Management for Competitive Advantage. Edisi ke-11. New York: McGraw-Hill/ Irwin.

Heizer, Jay \& Barry Render.2010. Manajemen Operasi. Edisi Ketujuh Buku 1. Jakarta: Salemba Empat

Murti Sumarni, Pengaruh Employee Retention Terhadap Turnover Intention dan Jinerja Karyawan, vol 8, 2011

Russell, R.S., dan B.W. Taylor III. 2011. Operations Management. Edisi ketujuh. New York: John Wiley \& Sons.

Undang Undang Nomor 3 Tahun 1982

Yamit, Zulian. (2003). Manajemen Kuantitatif Untuk Bisnis (Operations Research), BPFE, Yogyakarta. 